\title{
Magnesium as a diagnostic marker of cancer
}

\author{
Wojciech Marciniak ${ }^{1 *}$, Magdalena Muszyńska ${ }^{1}$, Katarzyna Jaworska-Bieniek², Katarzyna Kaczmarek², \\ Grzegorz Sukiennicki ${ }^{2}$, Marcin Lener ${ }^{2}$, Katarzyna Durda², Tomasz Huzarski ${ }^{2}$, Tomasz Byrski ${ }^{2}$, Jacek Gronwald², \\ Oleg Oszurek ${ }^{2}$, Cezary Cybulski ${ }^{2}$, Tadeusz Dębniak ${ }^{2}$, Antoni Morawski ${ }^{1}$, Anna Jakubowska², Jan Lubiński ${ }^{1,2}$
}

From Annual Conference on Hereditary Cancers 2014

Szczecin, Poland. 25-26 September 2014

Magnesium plays a key role in many essential cellular processes. It is recognized that magnesium deficiency may lead to many disorders like cardiovascular disease, diabetes mellitus, hypertension, myocardial infarction or even cancer. Connection between magnesium concentration in body fluids and cancer occurrence still becomes unclear. Magnesium ions are crucial cofactors for enzymes involved DNA repairing. Thereby magnesium deficiency may result in genomic instability and consequently cause cancer.

The aim of our study was to investigate if serum magnesium concentration may be useful biomarker for early detection of prostate and laryngeal cancer and also if serum $\mathrm{Mg}$ concentration may be marker of selection for $\mathrm{CT}$ of the lung, laryngeal examination, PSA levels or prostate biopsy. Independently we have investigated a prospective study where our aim was to investigate if the serum $\mathrm{Mg}$ concentration is a marker of increased breast cancer risk. We performed retrospective investigation in laryngeal cancer patients $(\mathrm{n}=123)$ and prostate cancer groups $(\mathrm{n}=166)$. Each group was compared with healthy controls group, which consists of equal to cases amount of controls. Controls and cases were matched by age, gender, negative supplementation status, negative status of hormonal contraceptives and smoking status. In the prospective study (sera collected before cancer diagnosis) Mg concentration was determined in BRCA (-) women and compared to controls. $\mathrm{Mg}$ serum levels $(<17000 \mu \mathrm{g} / \mathrm{l}$ and $>20800 \mu \mathrm{g} / \mathrm{l}$ ) are associated with 2-fold higher occurrence of laryngeal cancers. Magnesium serum level is not a useful marker for selection of the patients for prostate cancer screening. Finally, magnesium concentration may be a

\footnotetext{
* Correspondence: wojciech.marciniak90@gmail.com 'Department of Genetics and Pathology, International Hereditary Cancer Center, Pomeranian Medical University, Szczecin, Poland Full list of author information is available at the end of the article
}

marker for breast cancer risk in BRCA (-) patients but further investigation is needed.

\section{Authors' details}

${ }^{1}$ Department of Genetics and Pathology, International Hereditary Cancer Center, Pomeranian Medical University, Szczecin, Poland. ${ }^{2}$ Read - Gene, S.A., Grzepnica, Poland.

Published: 26 November 2015

doi:10.1186/1897-4287-13-S2-A6

Cite this article as: Marciniak et al:: Magnesium as a diagnostic marker of cancer. Hereditary Cancer in Clinical Practice 2015 13(Suppl 2):A6.

\author{
Submit your next manuscript to BioMed Central \\ and take full advantage of: \\ - Convenient online submission \\ - Thorough peer review \\ - No space constraints or color figure charges \\ - Immediate publication on acceptance \\ - Inclusion in PubMed, CAS, Scopus and Google Scholar \\ - Research which is freely available for redistribution \\ Submit your manuscript at \\ www.biomedcentral.com/submit
}

Ciomed Central

c 2015 Marciniak et al. This is an Open Access article distributed under the terms of the Creative Commons Attribution License (http:// creativecommons.org/licenses/by/4.0), which permits unrestricted use, distribution, and reproduction in any medium, provided the original work is properly cited. The Creative Commons Public Domain Dedication waiver (http://creativecommons.org/publicdomain/ zero/1.0/) applies to the data made available in this article, unless otherwise stated. 